${ }^{1}$ Atatürk University, Faculty of Medicine, Department of

Medical Microbiology e-posta:

ozgur.celebi@atauni.edu.tr ORCID: 0000-0003-4578-9474

Kafkas University, Faculty of Medicine, Department of Medical Microbiology, e-posta:

cigdemedabalkan@gmail.com ORCID: 0000-0003-3922-7758

${ }^{3}$ Erzurum Regional Training and Research Hospital.

Department of Infectious

Diseases and Clinical

Microbiology

e-posta:

dr.syilmaz@windowslive.com ORCID: 0000-0002-4123-0828

${ }^{4}$ Atatürk University, Faculty of Medicine, Department of

Veterinary Microbiology e-posta:

celebiidil@atauni.edu.tr

ORCID: 0000-0002-2355-0561

Atıf İçin: Özgür ÇELEBi, Çiğdem Eda BALKAN BOZLAK, Sibel IBA YILMAZ, Demet ÇELEBİ, Covid-

19 Şüphesi ile Başvuran Hastalarda Antikor Kimliği ve Diğer Parametreler, Balıkesir Medical Journal, 2021;5(1):9-17

Başvuru Tarihi: 15.01.2021 Kabul Tarihi: 01.02.2021 Yayınlanma Tarihi: 28.02.2021

Sorumlu Yazar: Çiğdem Eda BALKAN BOZLAK, Kafkas Üniversitesi, Kars

\section{Covid-19 Şüphesi ile Başvuran Hastalarda Antikor Kimliği ve Diğer Parametreler}

\author{
Antibody Identity in Suspected Covid-19 Patients and Other \\ Parameters
}

\author{
Özgür ÇELEBi ${ }^{1}$, Çiğdem Eda BALKAN BOZLAK ${ }^{2}$, Sibel iBA YILMAZ ${ }^{3}$, \\ Demet ÇELEBi ${ }^{4}$
}

Öz

Amaç: Bu çalışma, şüpheli Covid-19 hastalarında PCR ve antikor araştırmalarının bulgularını değerlendirmeyi amaçlamaktadır.

Gereç ve Yöntemler: Çalışmaya Covid-19 ve solunum yolu enfeksiyonu şüphesiyle hastanemize başvuran toplam 4206 hasta ve soğuk algınlığı gibi hafif klinik semptomları olan 232 hasta dahil edildi. Klinik tetkikler ve radyolojik taramalar sonrasında 4206 hastanın PCR testleri ve sadece hafif semptomları nedeniyle hastaneye kaldırılmayan 232 hastanın ise antikor tetkikleri yapıldı. Antikor tespiti için Covid-19 tedavisi gören hastalardan ve hiçbir semptomu veya hafif semptomu olmadığı için tedavi edilmeyen hastalardan alınan EDTA içeren kan örneklerinin plazmaları ayrılarak analiz edildi. Antikorların tespiti için Covid-19 IgM / IgG Hızlı Test kiti kullanıldı. Antikor taramaları hastalara Covid-19 tanısı konulduktan 10,17 ve 24 gün sonra üç kez tekrarlandı.

Bulgular: Şüpheli Covid-19 hastaları 27-87 yaşları arasındaydı. Bireylerin 2004'ü kadın (\%48) ve 2202'si erkekti (\%52). 4206 plazma örneğinden 276 örnek $(\% 6,56)$ RT- PCR pozitifti. PCR pozitif olan ve Covid-19 tedavisi gören hastaların 104'ü $(\% 37,68)$ kadın, 172 'si $(\% 62,32)$ erkek olarak saptandı.

Sonuç: Soğuk iklimde yaşayan ve gribal semptomları yıl içinde birkaç kez gösteren hastalarda Covid-19' a bağlı ölüm oranlarının daha ıımlı seyrettiği görülmektedir. Çalışmamız bu konu hakkında gelecekte yapılacak çalışmalara ışık tutması amacıyla bölgemiz verilerinin bir kısmını yansıtmaktadır.

Anahtar Kelimeler: Covid-19, pandemi, hasta bulguları

\section{ABSTRACT}

Aim: This study aimed to report laboratory findings of PCR and antibody research in suspect Covid-19 patients.

Materials and Methods: A total of 4206 patients with suspected Covid-19 and respiratory tract infection and 232 patients with mild clinical presentations such as cold who were admitted in hospitals were included in the study. After clinical examinations and radiological screenings, PCR tests of 4206 patients and antibody surveys of the 232 patients who were not hospitalized due to having only mild symptoms were carried out. For antibody detection, the plasmas of the EDTAcontaining blood samples that were collected from the patients who were treated for Covid-19 and patients who were not treated due to having no symptoms or mild symptoms were separated and analyzed. The 'Coronavirus disease IgM/IgG Rapid Test were used for the detection of antibodies. Antibody screenings were repeated three times 10, 17 and 24 days after the patients were diagnosed with Covid-19.

Results: The suspected Covid-19 were aged between 27 and 87 years and 2004 of the individuals were female (48\%) and 2202 of the individuals were male (52\%). Of 4206 plasma samples, 276 samples $(6.56 \%)$ were RT-PCR-positive. Of the patients who had a positive PCR and were treated for Covid-19, 104 patients (37.68\%) were female and 172 patients $(62.32 \%)$ were male.

Conclusion: It is observed that death rates due to Covid-19 are more moderate in patients living in a cold climate and showing flu symptoms several times a year. Our study is in the form of some of the data of our region in order to shed light on future studies on this subject.

Keywords: Covid-19, pandemic, patients' findings 


\section{INTRODUCTION}

Coronaviruses (CoV) are a virus family causing more severe clinical progression than cold including SARS-CoV (Severe Acute Respiratory Syndrome), which causes acute respiratory syndrome, and MERS (Middle East Respiratory Syndrome) which causes respiratory syndrome. The studies until today have revealed that MERS-CoV was transmitted from dromedary camel to humans, while SARS-CoV was transmitted from civet cats to humans $(1,2)$. Coronaviruses are a large zoonotic family and until recently, their various members did not infect humans and colonized in animals. Coronavirus subtypes such as HCoV-229E, HCoV-OL43, HCoV-NL63 and HKU1-CoV mostly cause cold in humans. SARS-CoV emerged as a previously unknown virus and caused the death of thousands of people and international declaration of a state of health emergency in 2003 . Until its emergence in a hospital in Zagra, Jordan, in 2012, the presence of MERS-CoV in animals and humans was not reported (3-6).

The World Health Organization (WHO) China Representative Office reported pneumonia cases of unknown origin in Wuhan in Hubei Province of China on 31 December 2019. In the first week of January 2020, the causative agent of the cases was identified to be a new Coronavirus (2019-nCoV), which was not previously identified in humans. Then, the infection was named Covid-19 and its causative agent was identified as SARSCoV-2 $(1,7,8)$. Coronaviruses are enveloped and single stranded viruses with positive polarity. They contain club-like projections. Thus, they are likened to crown and named Coronavirus. Their nucleic acid is RNA with a size of about $160 \mathrm{~nm}$. Coronaviruses belong to the Orthocoronavirinae family, a sub-family of the Coronaviridae family. They are divided into four genera and various subgenera. The new coronavirus is included in the Betacoronavirus $2 \mathrm{~b}$ type among the alfa, beta, gamma and delta coronavirus genera and its properties are exactly compatible with those of the Coronavirus family. Bat SARS-like coronavirus is very similar to Bat-SLCoVZC45. The causative agent of Covid-19 was identified to be SARS-CoV-2 that belongs to the Sarbecovirus subgenus of the Betacoronavirus genus, which also includes SARS-CoV and MERS-CoV (9-12). Many cases with symptoms compatible with fever and pneumonia infiltration in lungs were identified in the workers of a wholesale fish and live animal market in Wuhan. According to the WHO reports, deaths from Covid-19 were more common in older patients and patients with systemic diseases (hypertension, chronic lung disease, diabetes and immunosuppressive patients). The first important case was a 61-year-old Chinese woman and the case was reported from Taiwan on 13 January 2020. In the following days, Covid-19 cases rapidly spread in Iran, South Korea and Italy and death cases occurred at high rates. Covid-19 was then detected all around the world and the first case of Covid-19 in Turkey was detected on 11 March $2020(13,14)$. The exact infectious period of Covid-19 is unknown. It has been claimed that the infectious period starts one-two days before the onset of symptoms and ends after the symptoms disappear. The mean incubation time is 5-6 days (2-14 days) and the virus is transmitted via the droplets scattered by coughing and sneezing. These droplets are transmitted to hands of other people by contact and the virus infects people when the hands touch mouths, noses and eye mucosa. 


\section{MATERIALS AND METHODS}

Ethics committee approval was obtained [20.02.2020-317] This study was conducted in accordance with the Declaration of Helsinki Principles. A total of 4206 patients with suspected Covid-19 and respiratory tract infection and 232 patients with mild clinical presentations such as cold who were admitted in hospitals in Erzurum, Turkey (both state and university) were included in the study. After clinical examinations and radiological screenings, PCR tests of 4206 patients and antibody surveys of the 232 patients who were not hospitalized due to having only mild symptoms were carried out. The swab samples collected from the throat and nose mucosae of the patients with suspected Covid-19 using swabbing sticks were placed in capped, transport medium-containing tubes (Virocult, Medical Wire \& Equipment, UK) and sent to a reference microbiology laboratory to identify RNAs using the RT-PCR (BIORAD) method. For antibody detection, the plasmas of the EDTA-containing blood samples that were collected from the patients who were treated for Covid-19 and patients who were not treated due to having no symptoms or mild symptoms were separated and analyzed. The 'Coronavirus disease (Covid-19) IgM/IgG Antibody Rapid Test (Colloidal Gold) kits (Beijing Hotgen Biotech Co. Ltd., China) were used for the detection of antibodies. Antibody screenings were repeated three times 10, 17 and 24 days after the patients were diagnosed with Covid-19. The available and approved antibody screening kit does not show antibody titer. Thus, the samples were manually diluted with physiological saline solution in the ratios of $1 / 100$ and $1 / 200$. The sample plasmas were examined in three repetitions comprising their non-diluted, $1 / 100$ titrated and $1 / 200$ titrated versions.

\section{RESULTS}

The nucleocapsid and antibody results obtained using PCR for a total of 136 patients are shown in Table 1. The 4206 individuals with suspected Covid-19 were aged between 27 and 87 years and 2004 of the individuals were female (48\%) and 2202 of the individuals were male (52\%). Of 4206 plasma samples, 276 samples (6.56\%) were RT-PCR-positive. Of the patients who had a positive PCR and were treated for Covid-19, 104 patients (37.68\%) were female and 172 patients (62.32\%) were male. The clinical conditions of the treated patients according to their gender are shown in Table 2. Clinical findings in patients treated for COVID-19 are shown in Table 3. Computerized tomography (CT) and PCR results of suspicious patients are shown in Table 4. Three weeks of antibody development are shown in Table 5 . The titrated results of the antibody-positive samples are shown in Table 6. Laboratory examination results in patients diagnosed with COVID-19 by CT and PCR are shown in Table 7. Statistical analysis: The "Chi-Square" test was used to determine the degree of significance of the difference between the variables. If statistical analysis showed that the values were equal to or less than 0.05 , the difference between the rates was considered to be significant.

\begin{tabular}{|c|c|c|c|c|c|}
\hline Test & Positive & Negative & Total & x-square & P \\
\cline { 1 - 4 } Covid-19 (with PCR) & $10(7 \%)$ & $126(93 \%)$ & 136 & \multirow{2}{*}{22,054} & \multirow{2}{*}{$<0,001$} \\
\cline { 1 - 4 } Covid-19 (antibody) & $40(29 \%)$ & $96(71 \%)$ & 136 & & \\
\hline
\end{tabular}

Table 1. The nucleocapsid and antibody results obtained using PCR for total 136 patients 


\begin{tabular}{|l|l|l|l|l|}
\hline Clinical picture & Female & Male & x-square & $P$ \\
\hline Normal room & $147(\% 82,58)$ & $159(\% 76,44)$ & & \\
\cline { 1 - 4 } Intensive care unit & $24(\% 13,49)$ & $38(\% 18,27)$ & 2,202 & $<0,001$ \\
\cline { 1 - 3 } Intubated & $7(\% 3,93)$ & $11(\% 5,29)$ & & \\
\hline
\end{tabular}

Table 2. Clinical conditions of the patients treated according to their gender

\begin{tabular}{|c|c|c|c|c|}
\hline Clinical findings & Female & Male & x-square & $p$ \\
\hline Icy glass appearance+ paving stone & $132(\% 74,15)$ & $160(\% 76,92)$ & \multirow{4}{*}{1,432} & \multirow{4}{*}{$<0,001$} \\
\hline Ground glass density & $128(\% 71,91)$ & $176(\% 84,61)$ & & \\
\hline Consolidation & $60(\% 33,70)$ & $82(\% 39,42)$ & & \\
\hline Lesional vasodilation & $100(\% 56,17)$ & $114(\% 54,80)$ & & \\
\hline Clinical Findings & Female & Male & $x$-square & $p$ \\
\hline Fever & $38(\% 21,84)$ & $26(\% 12,26)$ & \multirow{5}{*}{9,273} & \multirow{5}{*}{$<0,001$} \\
\hline Cough & $58(\% 33,33)$ & $72(\% 33,96)$ & & \\
\hline Fever + cough & $44(\% 25,29)$ & $52(\% 24,53)$ & & \\
\hline RDS (respiratory distress syndrome) & $24(\% 13,79)$ & $40(\% 18,87)$ & & \\
\hline Fever + cough + RDS & $10(\% 5,75)$ & $22(\% \quad 10,38)$ & & \\
\hline
\end{tabular}

Table 3. Clinical findings in patients treated for COVID-19

\begin{tabular}{|c|l|l|c|c|}
\hline & Positive & Negative & x-square & $p$ \\
\hline CT & $386(\% 15,5)$ & $2104(\% 94,5)$ & 43,812 & $<0,001$ \\
\hline PCR & $232(\% 9,3)$ & $2258(\% 90,7)$ & & \\
\hline
\end{tabular}

Table 4. CT (computerized tomography) and PCR results of suspicious patients

\begin{tabular}{l|lc|cc|cc}
\hline & \multicolumn{2}{|c|}{ Day 10 } & \multicolumn{2}{c|}{ Day 17 } & \multicolumn{2}{c}{ Day 24 } \\
\cline { 2 - 7 } & Positive & Negative & Positive & Negative & Positive & Negative \\
\hline $\begin{array}{l}\text { Covid-19 (treated) } \\
\text { (N:102) }\end{array}$ & $\begin{array}{l}11 \\
(10.8 \%)\end{array}$ & $91(89.2 \%)$ & $\begin{array}{c}11 \\
(10.8 \%)\end{array}$ & $\begin{array}{c}91 \\
89.2 \%)\end{array}$ & $\begin{array}{c}13 \\
(12.7 \%)\end{array}$ & $89(87.3 \%)$ \\
\hline $\begin{array}{l}\text { Covid-19 } \\
\text { (untreated) } \\
\text { (n:232) }\end{array}$ & $\begin{array}{l}36 \\
(15.5 \%)\end{array}$ & $\begin{array}{c}196 \\
(84.5 \%)\end{array}$ & $\begin{array}{c}36 \\
(15.5 \%)\end{array}$ & $196(84.5)$ & $\begin{array}{c}36 \\
(15.5 \%)\end{array}$ & $(84.5 \%)$ \\
\hline
\end{tabular}

Table 5. Three weeks of antibody development in treated and untreated Covid-19 patients.

\begin{tabular}{lll|ll}
\hline & \multicolumn{2}{c|}{ Dilution (1/100) } & \multicolumn{2}{c}{ Dilution (1/200) } \\
\cline { 2 - 5 } & Positive & Negative & Positive & Negative \\
\hline $\begin{array}{l}\text { Covid-19 (treated) } \\
\text { (N:13) }\end{array}$ & $11(84.61 \%)$ & $2(15.39 \%)$ & $5(38.46 \%)$ & $8(61.54 \%)$ \\
\hline $\begin{array}{l}\text { Covid-19 (untreated) } \\
\text { (n:28) }\end{array}$ & $28(100 \%)$ & - & $25(89 \%)$ & $3(11 \%)$ \\
\hline
\end{tabular}




\begin{tabular}{|c|c|c|c|c|c|c|}
\hline & Female & & & Male & & \\
\hline & Normal & High & Low & Normal & High & Low \\
\hline Ure & $164(\% 92,13)$ & $14(\% 7,87)$ & $\mathrm{N} / \mathrm{A}$ & $190(\% 91,34)$ & $18(\% 8,66)$ & $\mathrm{N} / \mathrm{A}$ \\
\hline Creatine & $166(\% 93,25)$ & $12(\% 6,75)$ & $\mathrm{N} / \mathrm{A}$ & $187(\% 89,90)$ & $21(\% 10,10)$ & N/A \\
\hline AST & $148(\% 83,14)$ & $30(\% 6,86)$ & N/A & $200(\% 96,19)$ & $8(\% 3,85)$ & $\mathrm{N} / \mathrm{A}$ \\
\hline $\mathrm{ACT}$ & $140(\% 78,65)$ & $34(\% 21,35)$ & N/A & $198(\% 95,16)$ & $10(\% 4,88)$ & $\mathrm{N} / \mathrm{A}$ \\
\hline T. bilirubin & $162(\% 91,00)$ & $16(\% 9,00)$ & $\mathrm{N} / \mathrm{A}$ & $196(\% 94,23)$ & $12(\% 5,77)$ & $8(\% 3,85)$ \\
\hline LDH & $174(\% 97,75)$ & $2(\% 1,12)$ & $2(\% 1,12)$ & $194(\% 93,23)$ & $6(\% 2,88)$ & $10(\% 14,8)$ \\
\hline Natrium & $170(\% 95,50)$ & $\mathrm{N} / \mathrm{A}$ & $8(\% 4,51)$ & $196(\% 94,27)$ & $2(\% 1,00)$ & $7(\% 3,35)$ \\
\hline Potassium & $176(\% 98,87)$ & N/A & $2(\% 1,12)$ & $200(\% 96,15)$ & $1(\% 0,5)$ & $5(\% 2,40)$ \\
\hline Chlor & $162(\% 91,00)$ & $13(\% 7,00)$ & $3(\% 2,00)$ & $193(\% 92,79)$ & $10(\% 4,81)$ & $16(\% 7,69)$ \\
\hline CK-CKMB & $154(\% 86,51)$ & $13(\% 7,00)$ & $11(\% 6,18)$ & $170(\% 81,74)$ & $22(\% 10,57)$ & $11(\% 5,30)$ \\
\hline iNR & $163(\% 91,57)$ & $8(\% 4,51)$ & $7(\% 3,96)$ & $192(\% 92,309)$ & $5(\% 2,40)$ & N/A \\
\hline CRP & $160(\% 89,88)$ & $18(\% 10,12)$ & N/A & $194(\% 93,27)$ & $14(\% 6,73)$ & $\mathrm{N} / \mathrm{A}$ \\
\hline Sedim & $165(\% 92,70)$ & $10(\% 5,62)$ & $3(\% 1,68)$ & $150(\% 72,12)$ & $25(\% 12,01)$ & $33(\% \quad 15,87)$ \\
\hline Blood gas & $146(\% 82,02)$ & $2(\% 1,12)$ & $30(\% \quad 16,86)$ & $161(\% 77,40)$ & $2(\% 1,01)$ & $45(\% 21,60)$ \\
\hline Tropinin & $172(\% 96,62)$ & $6(\% 3,38)$ & $N / A$ & $199(\% 95,67)$ & $9(\% 4,33)$ & $N / A$ \\
\hline Ferritin & $138(\% 77,52)$ & $4(\% 2,24)$ & $36(\% 20,24)$ & $150(\% 72,12)$ & $32(\% 15,38)$ & $26(\% \quad 12,50)$ \\
\hline D-Dimer & $167(\% 94,82)$ & $11(\% 6,18)$ & $\mathrm{N} / \mathrm{A}$ & $192(\% 92,30)$ & $16(\% 7,70)$ & $\mathrm{N} / \mathrm{A}$ \\
\hline
\end{tabular}

Table 7. Laboratory examination results in patients diagnosed with COVID-19 by CT and PCR

\section{DISCUSSION}

The Covid-19 infection has become a clinical threat and a health issue worldwide (13). However, our knowledge of this mysterious virus is quite limited. Health workers and scientists did not have the opportunity to gather ample information about the virus, as they are busy with treating the patients whose numbers have exploded due to the threatening properties and rapid spread of the virus. Therefore, the findings of different publications do not always agree with each other. In addition, we began using the test kits for diagnosis without having the chance to sufficiently test the kits. Moreover, background knowledge, observation and comparison and medication used in the treatment of other diseases were used to stop the pandemic due to limited possibilities and options. After the confusion and chaos on day one and first month of the pandemic has dissipated and were replaced with calm when the pandemic was somewhat contained, the studies on the structure and clinical properties of the virus, the kits used for testing and suitable drugs for the treatment have begun in a relatively calmer environment. The RT-PCR used in the present study yields highly sensitive and accurate results (15-17). Our working team is well-experienced, as our university and hospital have a 60-year experience in healthcare. The test results obtained with RT-PCR are in compliance with the European 
standards. However, the same does not apply to the rapid diagnosis kits used in antibody detection. Low results were obtained when antibody formation (immunization) was examined (Table 1).

Detecting antibodies only in a few of the blood samples that were collected 10, 17 and 24 days after treatment from the patients who were diagnosed with Covid-19 and received treatment is quite worrisome. Should we attribute the findings whether to the recency of the use of the study kits and, thus, not having enough opportunity to test the kits and the low sensitivity of the kits or to a defective effect of the medications used during the treatments on the immune system? The increased number and volume of the antibodies in patients who had a mild or inapparent infection suggest the second question, which can only be answered when research and studies are advanced and increased. Although the number and titer of the antibodies in the patients with mild clinical signs were higher compared with those of the treated patients (Tablo:1 and 2), antibody formation in both groups was lower than that in other infections.

One of the primary purposes of the study was to investigate the immunity of the patients after the disease. A partial answer was found but near-exact answers can only be obtained after the introduction and use of more sensitive tests.

Erzurum is located in the East Anatolia region of Turkey and is the settlement with the highest altitude. Winter is long, snowy and cold in the region, which results in prevalent upper respiratory tract infections. The major agents of these infections are viruses. Influenza viruses are the leading causes of infections that occur in all seasons (albeit at a higher rate in winter), followed by Coronaviruses and Rhinoviruses. When Turkey was faced with the pandemic, it was already widespread across the world. Erzurum and its surroundings are underdeveloped regions in terms of medical infrastructure. Thus, the prevalence of zoonotic infections such as anthrax, brucellosis and typhoid are higher $(18,19)$. Due to these conditions, people living in the region are more exposed to infectious agents. Child mortality is higher compared with that in other regions. On the other hand, those who survive develop natural resistance to many infections.

With the detection of the first case in Turkey on 11 March 2020, cases emerged in Erzurum as well, albeit at a much lower rate. Iran, which had to endure the virus before Turkey, is close to Erzurum and its highway opening to Europe passes through Erzurum. Although its location rendered Erzurum riskier, the number of cases is much lower compared with those in rest of Turkey and European countries (21-26). Among the 4206 samples that were tested until today, only 276 samples (6.76\%) were PCR-positive and only 2 cases $(0.7 \%)$ were deceased, which are much better numbers compared with the averages in Europe and rest of the world. The two deceased patients were older than 86 years and one was previously diagnosed with lung sarcoidosis.

\section{CONCLUSION}

Considering the results of this study and other studies together, the good healthcare system and wellexperienced healthcare workers in Turkey, the colonization of the infectious agents in Erzurum (especially viral agents of upper respiratory tract diseases) and people's maintaining their lives under these conditions and the already stimulated and more active natural immunity cells suggest that the number of deaths due to Covid-19 
will be low. However, our knowledge of the disease and its agent and the diagnosis kits are limited and, thus, the results will change in the coming days and months. A third and an important result is that the immunity against Covid-19 is low according to the available testing resources. The antibody formation in patients with mild or no clinical signs is higher than patients who received a treatment. The difference between the two groups to the detriment of the treated patients might be associated with the medication used during the treatment.

\section{REFERENCES}

1. Cui J, Li F, Shi Z.L. Origin and evolution of pathogenic coronaviruses. Nat. Rev. Microbiol, 2019: $17 ; 181-192$.

2. Wu Z, McGoogan JM. Characteristics of and important lessons from the coronavirus disease 2019 (COVID-19) outbreak in China: summary of a report of 72314 cases from the Chinese Center for Disease Control and Prevention. JAMA, 2020; 24. doi:10.1001/jama.2020. 2648

3. Kolb A.F, Hegyi A, Siddell S.G. Identification of residues critical for the human coronavirus $229 \mathrm{E}$ receptor function of human aminopeptidase N. J. Gen. Virol, 1997: 78; 2795-2802.

4. Li W, Sui J, Huang I.C, Kuhn J.H, Radoshitzky S.R, Marasco W.A, Choe H, Farzan M. The S proteins of human coronavirus NL63 and severe acute respiratory syndrome coronavirus bind overlapping regions of ACE2. Virology, 2007: 367; 367-374.

5. Hulswit R.J.G, Lang Y, Bakkers M.J.G, Li W, Li Z, Schouten A, Ophorst B, van Kuppeveld F.J, BoonsG.J, Bosch B.J. HumancoronavirusesOC43andHKU1bindto9-O acetylated sialic acids via a conserved receptor-binding site in spike protein domain A. Proc. Nat. Acad. Sci, 2019: 116; 2681-2690.

6. Shi Y, Yu X, Zhao H, Wang H, Zhao R, Sheng J. Host susceptibility to severe COVID-19 and establishment of a host risk score: findings of 487 cases outside Wuhan. Crit Care, 2020: 24(1); 108.

7. Coronavirus 2019-nCoV, CSSE. Coronavirus 2019-nCoV Global Cases by Johns Hopkins CSSE. (Available from: https://gisanddata.maps.arcgis.com/apps/opsdashboard/index. html\#/bda7594740fd40299423467b48e9ecf6) (accession date 15.11.2020)

8. Xu X.T, Chen P, Wang J.F, Feng J.N, Zhou H, Li X, Zhong W, Hao P. Evolution of the novel coronavirus from the ongoing Wuhan outbreak and modeling of its spike protein for risk of human transmission. Sci.China Life Sci, 2020: 63(3); 457-460.

9. 9.Ling Z, Xu X, Gan Q, et al. Asymptomatic SARS-CoV-2 infected patients with persistent negative CT findings. Eur J Radiol. 2020;126; 108956.

10. McIntosh, Perlman S. Coronaviruses, including Severe Acute Respiratory Syndrome (SARS) and Middle East Respiratory Syndrome (MERS) In: Bennett JE, Dolin R, Blaser MJ (eds). Principles and Practice of Infectious Diseases. 8th edition. Philadelphia: Elsevier-Saunders, 2015: 1928-1936. 
11. Zhou P, Yang X.L, Wang X.G et al. A pneumonia outbreak associated with a new coronavirus of probable bat origin. Nature, 2020: 579; 270-273.

12. Wong A.C.P, Li X, Lau S.K.P, Woo P.C.Y. Global epidemiology of bat coronaviruses. Viruses, 2019 11;174.

13. WHO. Disease outbreak news. Novel coronavirus-China, Jan 12, 2020. https://www.who.int/csr/don/12-january-2020-novel-coronavirus-china/ en/ (accessed Feb 11, 2020).

14. 14.Yang $\mathrm{X}, \mathrm{Yu} \mathrm{Y}, \mathrm{Xu}$ J, et al. Clinical course and outcomes of critically ill patients with SARS-CoV-2 pneumonia in Wuhan, China: a single-centered, retrospective, observational study. Lancet Respir Med, 2020: $8 ; 475-481$.

15. Corman V.M, Müller MA, Costabel U, et al. Assays for laboratory confirmation of novel human coronavirus (hCoV-EMC) infection. Euro Surveill, 2012: 6;17(49); .20334

16. Türkiye Halk Sağlığı Kurumu Ulusal Mikrobiyoloji Standartları: Bulaşıcı Hastalıklar Laboratuvar Tanı Rehberi. TC Sağlık Bakanlığı Yayın No 934, Ankara, 2014

17. Centers for Disease Control and Prevention. Interim guidelines for collecting, handling, and testing clinical specimens from patients under investigation (PUIs) for Middle East respiratory syndrome coronavirus (MERSCoV) - Version 2.1. http://www.cdc.gov/coronavirus/ mers/guidelines-clinicalspecimens.html. accession date 01. 04.2020)

18. Balkan Ç.E, Çelebi S. Doğu Anadolu Bölgesinde Şarbon Etkeni ve Seroprevalansının Araştırılması.Türk Mikrobiyol Cem Derg, 2018: 48(1); 52-59.

19. Otter J.A, Donskey C, Yezli S, Douthwaite S, Goldenberg S.D, Weber D.J. Transmission of SARS and MERS coronaviruses and influenza virus in healthcare settings: the possible role of dry surface contamination. J Hosp Infect, 2016: 92; 235-50

20. Zaki A.M, van Boheemen S, Bestebroer T.M, Osterhaus A.D, Fouchier R.A. Isolation of a novel coronavirus from a man with pneumonia in Saudi Arabia. N Engl J Med 2012: 367; 1814-20.

21. Phan L.T, Nguyen T.V, Luong Q.C, et al. Importation and human-to-human transmission of a novel coronavirus in Vietnam. N Engl J Med, 2020: 382; 72-874

22. Rothe $C$, Schunk $M$, Sothmann $P$, et al. Transmission of 2019-nCoV infection from an asymptomatic contact in Germany. N Engl J Med. 2020; 382:970-971.

23. World Health Organization. Coronavirus disease (COVID-19) outbreak (https:// www .who .int). (accession date: 15.11 .2020$)$

24. Holshue M.L, DeBolt C, Lindquist S, et al. First case of 2019 novel coronavirus in the United States. N Engl J Med, 2020: 382; 929-936. 
25. National Health Commission of the People's Republic of China home page (http://www .nhc .gov .cn).( accession date:1 April 2020)

26. Rodriguez-Morales A.J, Gallego V, Escalera-Antezana J.P, et al. COVID-19 in Latin America: the implications of the first confirmed case in Brazil. Travel Med Infect Dis, 2020: 35; .101613. 